\title{
Erratum to: Workability study of concretes made with recycled mortar aggregate
}

\author{
Mônica B. Leite • João Gualberto \\ L. Figueirêdo Filho • Paulo R. L. Lima
}

Published online: 13 March 2013

(C) RILEM 2013

\section{Erratum to: Materials and Structures DOI 10.1617/s11527-012-0010-4}

Due to an unfortunate turn of events this article was published with an incorrect authors name under the article title and in the authors affiliations on the first page. Please find on this page the correct authors name that should be regarded as the final version by the reader.

The online version of the original article can be found under doi:10.1617/s11527-012-0010-4.

M. B. Leite $(\bowtie)$ · J. G. L. Figueirêdo Filho ·

P. R. L. Lima

Post-graduation Program of Civil and Environmental

Engineering, Department of Technology, State University

of Feira de Santana, Feira de Santana, BA, Brazil

e-mail: mbleite@pq.cnpq.br

J. G. L. Figueirêdo Filho

e-mail: jglffilho@yahoo.com.br

P. R. L. Lima

e-mail: lima.prl@pq.cnpq.br

M. B. Leite · P. R. L. Lima

PPGECEA/UEFS, Módulo 3, Labotec 2, Av.

Transnordestina, s/n-Novo Horizonte, Feira de Santana, BA 44036 900, Brazil 